\title{
PROSES BERPIKIR KREATIF SISWA SMP BERGAYA KOGNITIF IMPULSIF DAN REFLEKTIF DALAM MENGAJUKAN MASALAH MATEMATIKA
}

\author{
Syifa'ul Qulub \\ Pendidikan Matematika, Fakultas MIPA, Universitas Negeri Surabaya \\ E-mail: syifaulqulub16030174034@mhs.unesa.ac.id \\ Janet Trineke Manoy \\ Pendidikan Matematika, Fakultas MIPA, Universitas Negeri Surabaya \\ E-mail: janetmanoy@unesa.ac.id
}

\begin{abstract}
ABSTRAK
Pengajuan masalah dapat digunakan untuk melihat keterampilan berpikir kreatif. Dalam mengajukan masalah, siswa akan dipengaruhi oleh gaya kognitif. Gaya kognitif berdasarkan pada perbedaan waktu dan kecermatan siswa dalam merespon sesuatu dibedakan menjadi dua yaitu gaya kognitif impulsif dan reflektif. Tujuan penelitian ini yaitu mendeskripsikan proses berpikir kreatif siswa SMP bergaya kognitif impulsif dan reflektif dalam mengajukan masalah matematika, metode yang digunakan yaitu metode deskriptif dengan pendekatan kualitatif. Berdasarkan hasil tes MFFT dan TPM diperoleh dua subjek penelitian, yaitu satu subjek impulsif (SKI) dan satu subjek reflektif (SKR). Hasil penelitian menunjukkan bahwa subjek SKR mempunyai tingkat kecermatan yang lebih tinggi daripada subjek SKI, dengan proses berpikir kreatif kedua subjek sebagai berikut. Pada tahap mensintesis ide, subjek SKI tidak memerlukan waktu yang lama dalam memahami permasalahan sedangkan subjek SKR memerlukan waktu yang cukup lama dalam memahami permasalahan. Pada tahap membangun ide, subjek SKI hanya dapat membuat satu ide, sedangkan subjek SKR dapat membuat lebih dari satu ide. Pada tahap merencanakan penerapan, subjek SKI dan SKR samasama akan membuat soal tentang pembelian barang dalam paket, akan tetapi subjek SKI membuat kerangka soal terlebih dahulu sedangkan subjek SKR subjek memilih ide yang ia rasa dapat menyelesaikanya kemudian menggunakan buku paket sebagai referensi dalam membuat soal. Pada tahap menerapkan ide, subjek SKI dapat membuat satu soal sedangkan subjek SKR dapat membuat dua soal. Subjek SKI dan SKR sama-sama memeriksa kembali soal dan_penyelesaian yang dibuat untuk mengecek apakah sudah benar. Subjek SKI dan SKR yakin bahwa kedua soal dan penyelesaian yang dibuat sudah benar.
\end{abstract}

Kata Kunci: Proses Berpikir Kreatif, Pengajuan Masalah, Gaya Kognitif Impulsif dan Reflektif.

\begin{abstract}
Problem posing can be used to see creative thinking skills. In posing problems, students will be influenced by cognitive styles. Cognitive styles based on differences in time and accuracy of students in responding to something can be divided into two, namely impulsive and reflective cognitive styles. The purpose of this study is to describe the creative thinking process of junior high school students with impulsive and reflective cognitive style in posing mathematical problems. The method used is descriptive method with a qualitative approach. Based on the results of the MFFT and TPM tests, two research subjects were obtained, namely one impulsive subject (SKI) and one reflective subject (SKR). The results showed that the SKR subject had a higher level of accuracy than the SKI subject, with the creative thinking processes of the two subjects as follows. At the stage of synthesizing ideas, the SKI subject did not take a long time to understand the problem, while the SKR subject needed a long time to understand the problem. At the idea building stage, the SKI subject can only come up with one idea, while the SKR subject can create more than one idea. At the planning stage of implementation, the SKI and SKR subjects will both make questions about purchasing goods in packages, however, the SKI subject makes a question outline first while the SKR subject chooses an idea that he feels can solve then uses a textbook as a reference in making questions. At the stage of implementing the idea, the SKI subject can make one question while the SKR subject can make two questions. The SKI and SKR subjects both recheck the questions and the solutions made to check whether they are correct. The SKI and SKR subjects were sure that the two questions and their solutions were correct.
\end{abstract}

Keywords: Creative Thinking Process, Problem Posing, Impulsive and Reflective. 


\section{PENDAHULUAN}

Berpikir kreatif atau kreativitas merupakan salah satu kemampuan yang perlu diperhatikan dalam pembelajaran matematika. Prianggono, dkk. (2013) mengemukakan kreativitas merupakan hal yang jarang sekali diperhatikan dalam pembelajaran matematika karena biasanya menempatkan logika sebagai prioritas utama dalam pembelajaran dan menganggap kreativitas merupakan hal yang kurang penting. Akan tetapi, konsep matematika yang abstrak, membutuhkan berpikir kreatif untuk memahami dan menyelesaikan masalah matematika. Selain itu, berpikir kreatif dalam matematika dan dalam bidang lainnya merupakan bagian keterampilan hidup yang perlu dikembangkan terutama dalam menghadapi era informasi dimana suasana bersaing semakin ketat (Nurmasari dkk, 2014).

Menurut Siswono (2007), ada tiga komponen berpikir kreatif dalam mengajukan masalah diantaranya yaitu: kefasihan, fleksibilitas, dan kebaruan. Kefasihan merupakan kemampuan siswa untuk membuat keberagaman masalah yang diajukan sekaligus menyelesaikannya dengan benar. Fleksibilitas merupakan kemampuan siswa mengajukan masalah yang mempunyai cara penyelesaian yang berbeda-beda. Kebaruan merupakan kemampuan siswa mengajukan masalah yang berbeda dari masalah yang diajukan sebelumnya.

Berpikir kreatif merupakan bagian dari berpikir tingkat tinggi, karena kemampuan berpikir kreatif merupakan kompetensi kognitif tertinggi yang perlu dikuasai oleh setiap siswa. Berpikir kreatif melibatkan suatu proses berpikir yang disebut dengan proses berpikir kreatif, sedangkan tahapan seseorang berpikir kreatif yaitu mensintesis ide, membangun ide, merencanakan penerapan, dan menerapkan ide (Siswono, 2008).

Berpikir kreatif merupakan masalah penting dalam pembelajaran matematika, terutama dalam pengajuan masalah (Problem Posing), karena dengan pengajuan masalah dapat meningkatkan siswa untuk berpikir kritis dan kreatif (Julaikah dan Fitriyani, 2019). Pengajuan masalah dalam pembelajaran matematika mempunyai posisi yang strategis karena pengajuan masalah dapat mengembangkan pola berpikir siswa untuk mengajukan ide-ide dan dapat meningkatkan performa dalam pemecahan masalah (Siswono, 2008:40). Menurut Silver dkk (1996) "Problem posing is of central importance in the discipline of mathematics and in the nature of mathematical thinking”. Maksudnya, pengajuan masalah merupakan inti terpenting dalam disiplin matematika dan sifat pemikiran matematika. sehingga pengajuan masalah mempunyai peranan penting dalam pembelajaran matematika terutama dalam meningkatkan berpikir kreatif siswa.
Silver dan Cai (1996) mengaplikasikan pengajuan masalah kedalam tiga bentuk: pengajuan pre-solusi (presolustion posing) yaitu siswa membuat soal dari situasi yang diajukan; pengajuan didalam solusi (within-solution posing) yaitu siswa merumuskan ulang soal seperti yang telah diselesaikan; pengajuan setelah solusi (post solution posing) yaitu siswa memodifikasi tujuan atau kondisi soal yang telah diselesaikan untuk membuat soal yang baru. Dalam penelitian ini, digunakan pengajuan masalah tipe pre-solution, karena menuntut siswa memahami materi berkaitan dengan informasi yang diberikan, menganalisis apakah informasi tersebut cukup atau tidak untuk membuat suatu masalah serta mengaplikasikan informasi yang diberikan untuk membuat suatu masalah, sehingga dengan tahapan ini dapat meningkatkan berpikir kreatif siswa.

Penelitian tentang berpikir kreatif siswa dalam pengajuan masalah telah banyak dilakukan salah satunya yaitu penelitian Hidayat dan Anggraini (2019). Penelitian tersebut menunjukkan bahwa dengan pengajuan masalah dapat melihat proses berpikir kreatif siswa. Proses berpikir kreatif siswa dalam pengajuan masalah ditinjau menggunakan indikator berpikir kreatif dari Wallas (1926), yaitu tahap persiapan, inkubasi, iluminasi, dan verifikasi. Hasil penelitian menunjukkan bahwa dalam proses berpikir kreatif dalam mengajukan masalah, masing-masing kategori, yaitu kategori 1 (IQ 110-119), kategori 2 (IQ 100-109), dan kategori 3 (90-99) hanya melewati 3 tahap proses berpikir kreatif yaitu tahap persiapan, iluminasi, dan verifikasi. Proses berpikir kreatif ketiga kategori berbeda-beda meski hanya melewati 3 tahap proses berpikir kreatif yang sama. Dengan demikian, bahwa dengan pengajuan masalah, guru dapat mengetahui seberapa jauh proses berpikir kreatif siswa sehingga guru dapat merancang model atau strategi pembelajaran yang bertujuan mengembangkan berpikir kreatif.

Setiap siswa memiliki karakteristik yang berbeda dengan siswa yang lain, karena setiap siswa mempunyai kemampuan dan cara berpikir yang berbeda pula. Perbedaan itu dapat meliputi cara siswa memperoleh, memproses, mengorganisasikan, dan mengingat informasi yang ia peroleh dari sumber belajar yang dapat menjelaskan perbedaan keberhasilan individu dalam belajar (Pagiling, 2017). Perbedaan-perbedaan antar pribadi yang menetap dalam cara menyusun dan mengolah informasi serta pengalaman-pengalaman disebut gaya kognitif (Slameto 2013). Adanya perbedaan karakteristik pada setiap siswa dengan harapan pembelajaran yang dilakukan mencapai hasil yang maksimal maka guru perlu memperhatikan gaya kognitif yang dimiliki masingmasing siswa. 
Dalam mengajukan soal/masalah, terdapat informasi yang diterima, selanjutnya informasi itu diproses, disimpan, kemudian digunakan dalam membuat soal/masalah, sehingga dalam mengajukan masalah siswa akan dipengaruhi oleh gaya kognitifnya. Gaya kognitif yang didasarkan atas perbedaan konseptual tempo dalam memproses informasi atau dalam merespon suatu stimulus serta keakuratan jawaban dari respon yang diberikan terbagi 2 yaitu gaya kognitif impulsif dan gaya kognitif reflektif (Kagan, 1966), Proses berpikir siswa dengan gaya kognitif impulsif berbeda dengan proses berpikir siswa dengan gaya kognitif reflektif.

Penelitian tentang gaya kognitif impulsif dan reflektif menunjukkan adanya perbedaan waktu yang digunakan siswa serta keakuratan jawaban yang dihasilkan (Rozencwajg \& Corroyer, 2005; Warli, 2010; Al-silami, 2010; Azhil dkk, 2017; dan Ramadhan dkk, 2019). Adanya perbedaan tersebut menarik perhatian peneliti untuk melakukan penelitian tentang proses berpikir kreatif siswa bergaya kognitif impulsif dan reflektif dalam mengajukan masalah matematika.

Berdasarkan latar belakang di atas, peneliti tertarik untuk membuat penelitian dengan judul "Proses Berpikir Kreatif Siswa SMP Bergaya Kognitif Impulsif dan Reflektif dalam Mengajukan Masalah Matematika".

\section{METODE}

Jenis penelitian yang digunakan yaitu penelitian kualitatif yang bertujuan untuk mendeskripsikan proses berpikir kreatif siswa bergaya kognitif impulsif dan reflektif dalam mengajukan masalah matematika. Sedangkan metodenya yaitu tes dan wawancara. Tes yang digunakan terdiri dari tes gaya kognitif MFFT (Matching Familiar Figure Test) yang dikembangkan oleh warli (2010) dan tes pengajuan masalah (TPM).

Subjek penelitian yaitu siswa SMP kelas VIII yang telah menerima materi Sistem Persamaan Linier Dua Variabel (SPLDV). Penentuan subjek penelitian, pertama siswa diberi tes gaya kognitif MFFT kemudian siswa diberi tes pengajuan masalah. Tes gaya kognitif MFFT dianalisis didasarkan pada lama waktu yang digunakan dan keakuratan jawaban yang dihasilkan siswa. Siswa dikelompokkan bergaya kognitif impulsif jika waktu menjawab kurang dari mean waktu menjawab seluruh siswa dan banyaknya kesalahan lebih dari mean seluruh siswa. Sedangkan siswa dikategorikan bergaya kognitif reflektif jika waktu menjawab lebih dari mean waktu seluruh siswa dan banyaknya kesalahan lebih kecil dari mean seluruh siswa. Selanjutnya dipilih dua subjek penelitian yang terdiri dari satu subjek bergaya kogntif impulsif dan satu subjek bergaya kognitif reflektif.

Instrumen penelitian terdiri dari instrumen utama yaitu peneliti dan instrumen pendukung. Instrumen pendukung terdiri dari lembar tes gaya kognitif MFFT, lembar tes pengajuan masalah, dan pedoman wawancara. Pedoman wawancara digunakan untuk mendapat gambaran lebih jelas mengenai data yang belum tertuang dalam hasil tes subjek saat mengajukan masalah.

Berikut tes pengajuan masalah yang diberikan kepada subjek.

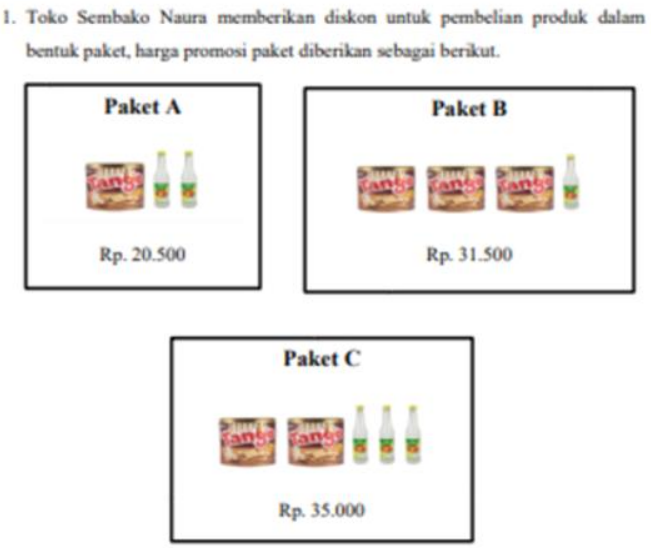

Setiap barang dapat dibeli secara terpisah, akan tetapi dikenakan pajak sebesoy $10 \%$ tiap barangrya.

Gambar 1. Tes Pengajuan Matematika

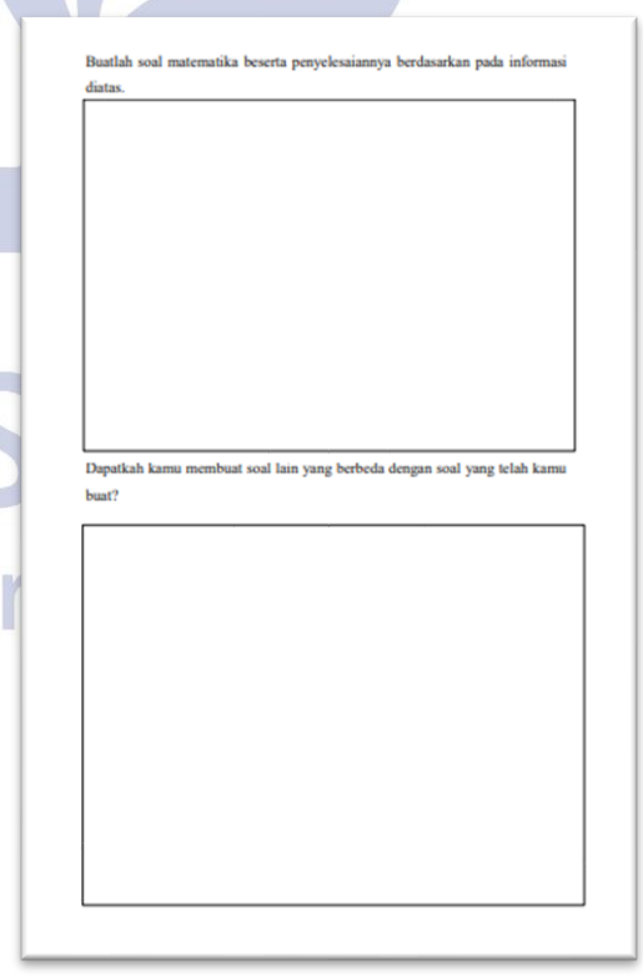

Gambar 2. Tes Pengajuan Matematika

Teknik yang digunakan dalam penelitian ini dilakukan 3 tahap analisis, yaitu teknik analisis data hasil tes gaya kognitif, teknik analisis data hasil tes pengajuan masalah, 
dan teknik analisis data hasil wawancara yang terdiri dari reduksi data, penyajian data, dan penarikan kesimpulan. Analisis tes pengajuan masalah juga berdasarkan indikator proses berpikir kreatif dari Siswono (2008) disajikan pada Tabel 1.1 berikut.

Tabel 1. Indikator Proses Berpikir Kreatif Siswa Dalam Mengajukan Masalah.

\begin{tabular}{|c|c|c|}
\hline No. & Tahap & Indikator \\
\hline \multirow[t]{2}{*}{1.} & \multirow[t]{2}{*}{$\begin{array}{l}\text { Mensintesis } \\
\text { Ide }\end{array}$} & $\begin{array}{l}\text { Mengumpulkan informasi } \\
\text { dari soal/masalah yang } \\
\text { diberikan. }\end{array}$ \\
\hline & & $\begin{array}{l}\text { Menentukan konsep-konsep } \\
\text { yang relevan dengan } \\
\text { soal/masalah yang diberikan }\end{array}$ \\
\hline \multirow[t]{2}{*}{2.} & \multirow[t]{2}{*}{$\begin{array}{l}\text { Membangun } \\
\text { Ide }\end{array}$} & $\begin{array}{l}\text { Membangun beberapa ide } \\
\text { dari informasi yang telah } \\
\text { diketahui sebelumnya. }\end{array}$ \\
\hline & & $\begin{array}{l}\text { Menggabungkan beberapa } \\
\text { ide dengan informasi yang } \\
\text { telah diketahui sebelumnya. }\end{array}$ \\
\hline \multirow[t]{4}{*}{3.} & \multirow[t]{4}{*}{$\begin{array}{l}\text { Merencanakan } \\
\text { Penerapan }\end{array}$} & $\begin{array}{l}\text { Memilih ide yang akan } \\
\text { diterapkan dalam pembuatan } \\
\text { soal/masalah. }\end{array}$ \\
\hline & & $\begin{array}{l}\text { Mengumpulkan informasi } \\
\text { dari ide yang telah dipilih. }\end{array}$ \\
\hline & & $\begin{array}{l}\text { Mengembangkan ide yang } \\
\text { akan digunakan untuk } \\
\text { membuat soal/masalah. }\end{array}$ \\
\hline & & $\begin{array}{l}\text { Memilih ide yang berbeda } \\
\text { yang akan digunakan untuk } \\
\text { membuat soal/masalah. }\end{array}$ \\
\hline \multirow[t]{4}{*}{4.} & \multirow[t]{4}{*}{$\begin{array}{l}\text { Menerapkan } \\
\text { ide }\end{array}$} & $\begin{array}{l}\text { Menggunakan ide yang telah } \\
\text { dipilih untuk membuat } \\
\text { soal/masalah. }\end{array}$ \\
\hline & & $\begin{array}{l}\text { Menggunakan ide yang lain } \\
\text { yang telah disusun untuk } \\
\text { membuat soal/masalah. }\end{array}$ \\
\hline & & $\begin{array}{l}\text { Memeriksa soal dan, strategi } \\
\text { penyelesaian, dan jawaban } \\
\text { yang dibuat } \\
\text { permasalahan } \\
\text { diberikan. }\end{array}$ \\
\hline & & $\begin{array}{l}\text { Memberi argumen bahwa } \\
\text { soal, strategi penyelesaian, } \\
\text { dan jawaban yang dibuat } \\
\text { sudah benar. }\end{array}$ \\
\hline
\end{tabular}

\section{HASIL DAN PEMBAHASAN}

Berdasarkan hasil tes gaya kognitif MFFT diperoleh 9 siswa bergaya kognitif impulsif dan 5 siswa bergaya kognitif reflektif. Dari data yang ada, peneliti memilih 2 subjek penelitian yaitu satu subjek bergaya kognitif impulsif dan satu subjek bergaya kognitif reflektif. Subjek penelitian juga dipilih berdasarkan jenis kelamin yang sama. Hal tersebut dilakukan agar data yang diperoleh tidak ada perbedaan karena perbedaan jenis kelamin subjek. Berdasarkan analisis data hasil Tes Pengajuan Masalah (TPM) dan wawancara yang telah dilakukan kepada kedua subjek penelitian, disajikan sebagai berikut.

\section{Analisis data proses berpikir kreatif subjek bergaya kognitif impulsif (SKI) dalam mengajukan masalah matematika.}

Berikut soal dan penyelesaian yang disajikan subjek SKI.

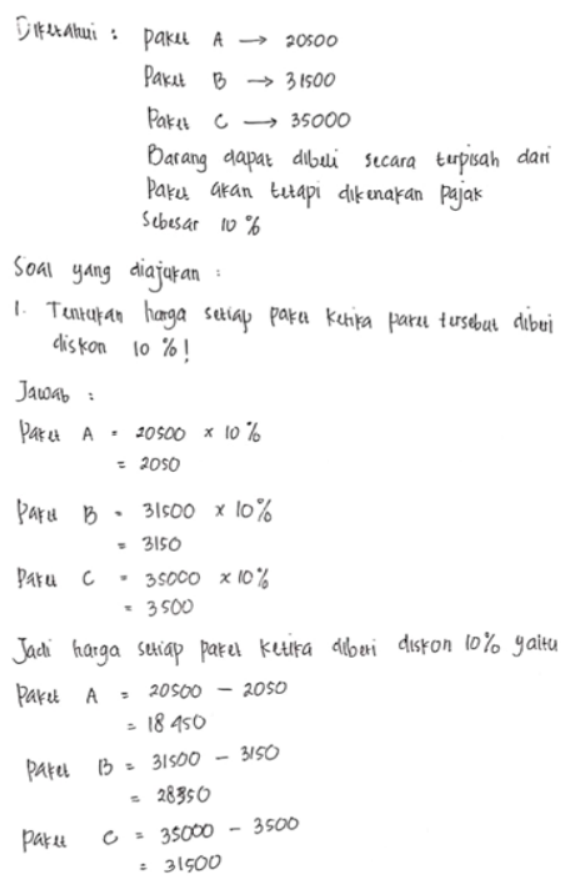

Berikut wawancara yang dilakukan antara subjek SKI dengan peneliti.

Peneliti : bagaimana kamu mengumpulkan informasi dari soal/masalah yang diberikan?

SKI $C$ : saya mengumpulkan informasi dengan membaca dan memahami informasi yang diberikan kemudian menganalisisnya.

Peneliti : informasi apa yang kamu dapatkan dari tes yang diberikan?

SKI : menurut saya informasi yang diberikan berhubungan proses penjualan barang dalam paket.

Peneliti : apakah kamu pernah menemukan konsep yang relevan dengan informasi yang diberikan.

SKI : ya, saya penah menjumpai konsep yang relevan dengan informasi yang diberikan yaitu tentang pembelian barang.

Peneliti : apakah ide yang kamu miliki hanya satu atau lebih?

SKI : saya hanya dapat membangun satu ide. 
Peneliti : bagaimana proses kamu membangun ide untuk membuat soal?

SKI : saya membangun ide dengan melihat informasi pada tes dan mengingat soal yang relevan yang pernah saya kerjakan kemudian saya membuat kerangka soal.

Peneliti : bagaimana kamu mengumpulkan informasi dari ide yang telah kamu dapat?

SKI : saya mengumpulkan informasi dengan melihat tes dan pengalaman saya ketika mengerjakan soal yang relevan.

Peneliti : apakah kamu yakin ide tersebut mempunyai hubungan dengan informasi pada tes?

SKI : saya yakin, karena ide yang saya buat berhubungan masih mempunyai keterkaitan dengan informasi pada tes.

Peneliti : bagaimana kamu menggunakan ide yang telah kamu dapat untuk membuat soal?

SKI : ide yang saya dapat itu tentang penjualan barang, disitu saya membuat soal tentang penjualan barang dalam paket akan tetapi paket tersebut diberi diskon sebesar 10\% untuk setiap harga paket yang telah ditentukan.

Peneliti : menurut kamu apakah soal dan strategi penyelesaian yang kamu buat sudah benar dan sesuai dengan informasi yang diberikan?

SKI : menurut saya sudah benar dan sesuai dengan informasi yang diberikan, saya sebelumnya juga mengecek kembali soal dan strategi penyelesaian yang telah saya buat untuk memastikan benar atau tidak.

Berdasarkan hasil pekerjaan subjek SKI dan wawancara, diperoleh informasi proses berpikir kreatif siswa dalam mengajukan masalah yaitu sebagai berikut.

\section{a. Mensintesis Ide}

Pada tahap mensintesis ide, setelah mendapatkan tes pengajuan masalah (TPM), yang dilakukan subjek SKI yaitu membaca dan memahami informasi yang diberikan. Pertama, subjek SKI melihat gambar paket-paket yang telah ditentukan. Ada tiga paket dan setiap paket mempunyai harga yang berbedabeda. Subjek SKI fokus pada paket yang ditentukan. Pada tahap ini, subjek SKI sempat mengalami kesulitan dalam memahami dan menganalisis informasi karena ia belum pernah menjumpai soal yang sama dengan informasi pada tes. Subjek SKI ingat bahwa ia pernah mengerjakan soal yang relevan yaitu tentang pembelian barang yang cara penyelesaiannya pertama dimodelkan kemudian dicari penyelesaiannya menggunakan metode eliminasi dan substitusi. Subjek SKI berpikir bahwa ia akan menggunakan pengalaman tersebut untuk membuat soal, akan tetapi tentunya dengan konsep yang agak berbeda dengan soal yang pernah ia kerjakan. Subjek SKI pada tahap ini tidak memerlukan waktu yang lama dalam memahami informasi. Waktu yang digunakan subjek SKI sekitar 10 menit untuk memahami informasi.

b. Membangun Ide
Tahap membangun ide merupakan hasil dari tahap mensintesis ide. Pada tahap ini, subjek SKI tidak memerlukan waktu yang lama dalam membangun ide, ide yang dihasilkan juga hanya satu. Subjek SKI membangun ide dengan melihat informasi pada tes, subjek SKI masih fokus pada paket yang telah ditentukan. Selain itu, subjek SKI juga menulis informasi yang diberikan di lembar jawaban. Setelah itu, subjek SKI mengaitkannya dengan pengalaman ketika ia mengerjakan soal yang relevan yaitu tentang pembelian barang. Dengan demikian, subjek SKI mampu membangun ide untuk membuat soal yaitu tentang soal penjualan barang akan tetapi setiap paket akan diberi diskon. Subjek SKI membuat ide tersebut karena informasi yang subjek SKI fahami pada tes yaitu penjualan barang-barang dalam bentuk paket, pembelian akan dikenakan pajak ketika membeli barang terpisah dari paket. Maka dari itu, subjek SKI berpikir ia menggunakan ide tersebut. Setelah mendapat ide, subjek SKI kemudian membuat kerangka soal yang akan digunakan sebagai bahan untuk membuat soal.

c. Merencanakan Penerapan

Pada tahap merencanakan penerapan, subjek SKI langsung menggunakan ide yang telah didapat, karena ide yang didapat hanya satu. Namun sebelum menggunakannya, subjek SKI mengumpulkan informasi-informasi yang mendukung serta mengembangkan ide dengan membaca kembali tes dan juga mengingat ketika ia mengerjakan soal yang relevan dengan tes. Ide yang digunakan untuk membuat soal yaitu tentang pemberian diskon untuk setiap paket. Subjek SKI yakin bahwa ide tersebut sudah sesuai dengan informasi yang ada pada tes. Karena pada tes, informasi yang diberikan tentang penjualan barang dalam bentuk paket meski konsep yang digunakan pada soal berbeda akan tetapi masih mempunyai keterkaitan. Sehingga dengan mengumpulkan dan mengembangakan ide, subjek SKI mampu membuat perencanaan tentang soal yang akan dibuat.

d. Menerapkan Ide

Pada tahap menerapkan ide, subjek SKI merealisasikan ide yang telah didapat. Dalam hal ini subjek SKI membuat soal tentang penjualan barang dalam paket dengan memberikan diskon setiap paketnya sebesar $10 \%$. Hal tersebut tidak sesuai dengan informasi yang ada pada tes, karena pada tes yang diberikan menunjukkan ketika barang dibeli secara terpisah dari paket akan dikenakan pajak sebesar 10\%. Setelah itu, subjek SKI membuat penyelesaian dari soal yang telah dibuat. Soal yang diajukan oleh subjek SKI kurang tepat karena tidak sesuai dengan informasi yang diberikan. Hal tersebut dikarenakan subjek SKI terlalu cepat dan kurang teliti dalam menyimpulkan informasi yang diberikan sehingga informasi yang didapat kurang tepat dan juga soal yang diajukan kurang tepat. Hal tersebut sejalan dengan pendapat Kagan (1966) yang menjelaskan bahwa siswa yang bergaya 
kognitif impulsif cenderung menggunakan waktu yang singkat akan tetapi jawaban yang dihasilkan cenderung salah. Setelah membuat soal dan juga penyelesaian subjek mengecek kembali soal dan strategi penyelesaian untuk memastikan sudah benar atau masih ada yang salah. Subjek SKI yakin bahwa soal dan strategi penyelesaian yang dihasilkan sudah benar. Subjek SKI juga berpendapat bahwa soal yang dibuat ada hubungannya dengan informasi yang diberikan karena soal tersebut berhubungan dengan proses penjualan barang di toko.

2. Analisis data proses berpikir kreatif subjek bergaya kognitif reflektif (SKR) dalam mengajukan masalah matematika.

Berikut soal dan penyelesaian yang disajikan subjek SKR.

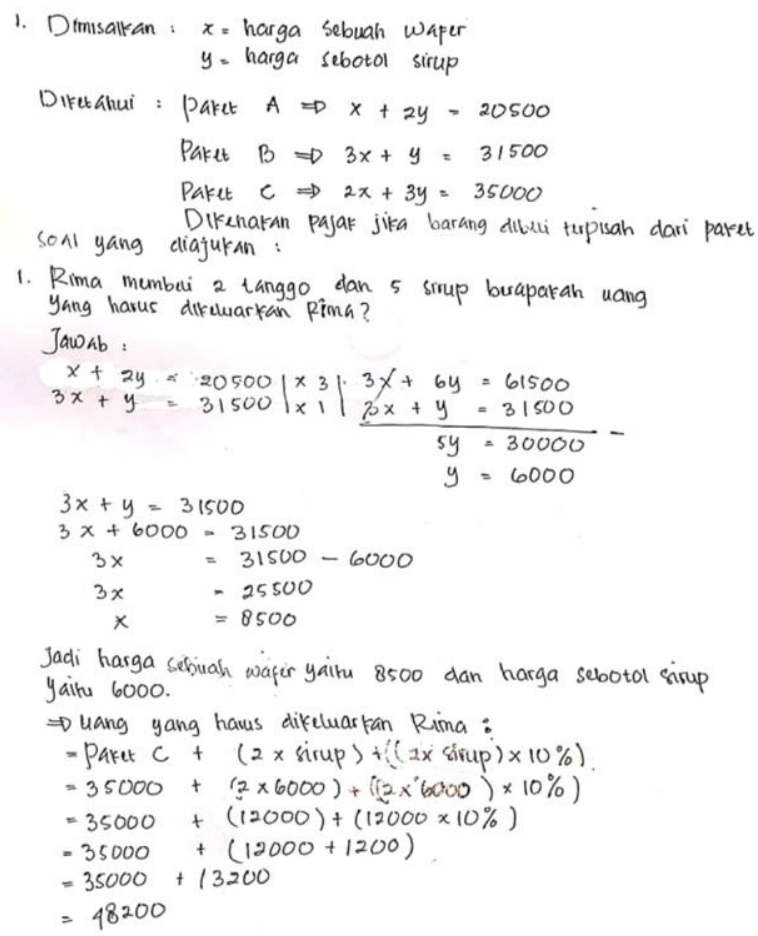

Jadi uang yang harus dikeluarkan Rima yaitu 48200

Gambar 4. Hasil Tes Tulis Subjek SKR

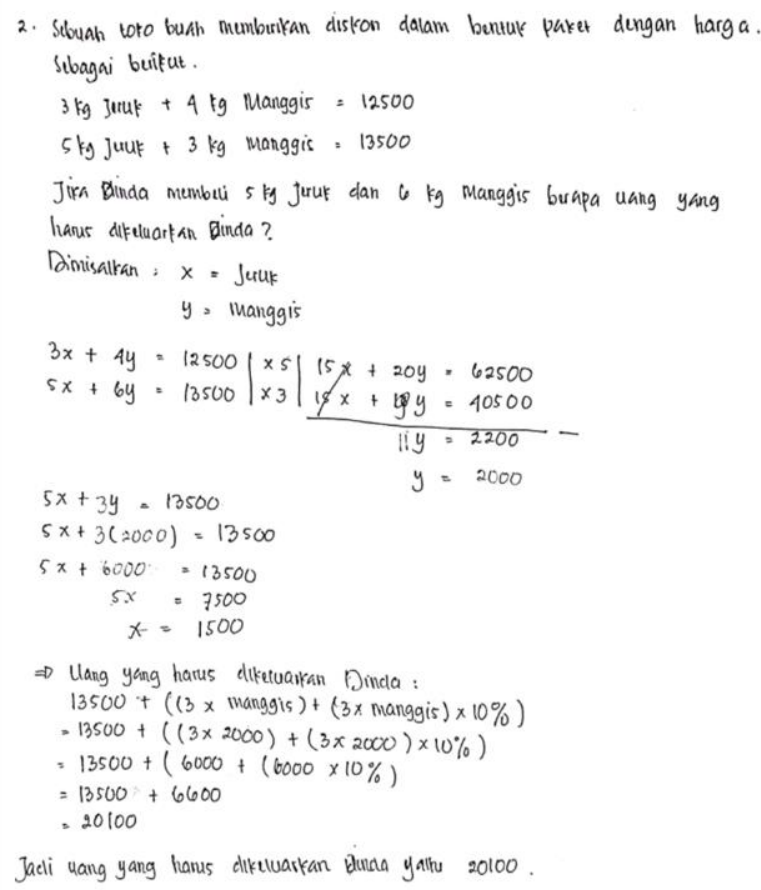

Gambar 5. Hasil Tes Tulis Subjek SKR

Berikut wawancara yang dilakukan antara subjek SKR dengan peneliti.

Peneliti : bagaimana cara kamu mengumpulkan informasi dari tes yang diberikan?

SKR : saya mengumpulkan informasi dengan membaca secara berulang-ulang agar saya faham informasi pada tes.

Peneliti : konsep apa yang kamu temukan pada tes yang diberikan?

SKR : menurut saya konsep yang saya temukan tentang penjualan barang dalam bentuk paket.

Peneliti : pernakah kamu menjumpai konsep yang relevan dengan informasi pada tes?

SKR : saya pernah menjumpai konsep yang relevan, akan tetapi konsepnya beda, soal yang pernah saya kerjakan tentang penjualan barang tapi tidak dalam bentuk paket.

Peneliti : apakah ide yang kamu miliki hanya satu atau lebih?

SKR : saya memiliki ide lebih dari satu.

Peneliti : ide yang seperti apa yang kamu dapatkan?

SKR : tentang penjualan barang dalam paket tapi dibelinya secara terpisah.

Peneliti : bagaimana proses kamu untuk membangunkan ide untuk membuat soal/masalah?

SKR : saya membangun ide dengan mengingat masalah yang hampir sama dengan informasi yang diberikan dan juga membaca kembali informasi pada tes.

Peneliti : ide seperti apa yang kamu gunakan untuk membuat soal/masalah?

SKR : saya memilih ide yang berkaitan dengan pembelian barang yang terpisah dari paket. 
Peneliti : bagaimana cara kamu mengembangkan ide tersebut untuk dijadikan sebagai soal/masalah?

SKR : saya membaca kembali informasi dan melihat soal-soal pada buku paket yang mempunyai keterkaitan dengan informasi pada tes.

Peneliti : ketika kamu memilih ide yang kamu gunakan, apakah kamu mempunyai cara untuk penyelesaiannya?

SKR : iya saya tau cara menyelesaikan dari ide yang saya pilih karena saya memilih ide yang sekiranya saya dapat menyelesaikannya.

Peneliti : bagaimana kamu menggunakan ide yang telah kamu pilih untuk membuat soal/masalah?

SKR : saya merangkai kata-kata terlebih dahulu dalam menggunakan ide yang telah dipilih untuk membuat soal.

Peneliti : menurut kamu apakah soal, strategi penyelesaian yang kamu buat sudah benar? Jelaskan!

SKR : sudah, soal yang saya buat kan pembelian barang terpisah dari paket dan dalam informasi yang diberikan itu dikenakan pajak $10 \%$ jadi pertama dicari harga perbarangnya terlebih dahulu, setelah diketahui kemudian satu barang tersebut dikenakan pajak sebesar $10 \%$.

Peneliti : apakah kamu menggunakan ide lain/berbeda yang telah kamu susun sebelumnya untuk membuat soal/masalah? Jika iya, bagaimana kamu menggunakan ide tersebut untuk membuat soal?

SKR : iya, soal kedua yang saya buat tentang pembelian, bedanya dengan yang pertama tentang nama barang yang dibeli.

Berdasarkan hasil pekerjaan subjek SKR dan wawancara, diperoleh informasi proses berpikir kreatif siswa dalam mengajukan masalah yaitu sebagai berikut.

a. Mensintesis Ide

Pada tahap mensintesis ide, langkah pertama yang dilakukan subjek yaitu membaca dan mencermati informasi pada tes pengajuan masalah (TPM). Pertama subjek SKR melihat paket-paket yang ditentukan, kemudian membaca informasi yang diberikan yaitu dikenakan pajak sebesar $10 \%$ jika membeli barang terpisah dari paket. Subjek SKR fokus pada informasi yang diberikan. Awalnya subjek SKR merasa kesulitan dalam memahami dan menganalisis informasi, akan tetapi subjek SKR membaca informasi pada tes secara berulang-ulang. Subjek SKR ingat bahwa ia pernah mengerjakan soal yang relevan dengan informasi pada tes yaitu tentang pembelian barang, akan tetapi konsepnya berbeda. Soal yang pernah ia kerjakan yaitu soal cerita yang dicari harga untuk setiap barang. Cara menyelesaikannya yaitu pertama dimodelkan dan dicari penyelesaiannya menggunakan metode eliminasi dan substitusi. Subjek SKR berpikir ia akan menggunakan pengalaman tersebut untuk membuat beberapa ide. Subjek SKR berpendapat bahwa informasi yang diberikan berhubungan dengan penjualan barang disuatu toko tapi dalam bentuk paket. Dalam hal ini subjek memerlukan waktu yang cukup lama dalam memahami informasi yang diberikan. Waktu yang digunakan sekitar 15 menit.

b. Membangun Ide

Tahap membangun ide merupakan hasil dari tahap mensintesis ide. Pertama, subjek melihat informasi pada tes. Subjek SKR masih fokus pada informasi yang diberikan yaitu akan dikenakan pajak sebesar $10 \%$ jika membeli barang dalam paket secara terpisah. Subjek SKR menghubungkan pengetahuan yang dimiliki dengan informasi pada tes. Kemudian, dari penggabungan tersebut subjek SKR mampu membuat beberapa ide. Setelah itu, pertama yang dilakukan subjek yaitu memisalkan setiap nama barang pada tes terlebih dahulu. Subjek SKR memisalkan nama barang menggunakan huruf $x$ dan $y, x$ untuk wafer dan $y$ untuk sirup. Setelah menulis informasi, subjek SKR menggunakannya untuk membuat ide menjadi soal. Subjek SKR berencana bahwa soal yang akan dibuat berhubungan dengan pembelian barang akan tetapi dibeli secara terpisah dari paket. Namun, subjek SKR membaca kembali informasi pada tes untuk memastikan ide yang telah diperoleh sesuai dengan informasi yang diberikan.

c. Merencanakan Penerapan

Pada tahap merencanakan penerapan, subjek SKR memilih ide yang akan digunakan untuk membuat soal. Subjek SKR akan membuat soal yang ia rasa dapat menyelesaikan. Hal ini dilakukan agar penyelesaian dari soal yang dibuat benar. Dari ide yang telah diperoleh, subjek SKR akan membuat dua soal. Soal pertama dan soal yang kedua tentang pembelian barang tapi terpisah dari paket. Subjek SKR akan membuat soal yang pertama dan kedua agak berbeda. Subjek SKR berencana bahwa akan menggunakan nama barang yang berbeda pada dua soal yang dibuat dan tentunya pertanyaan yang diajukan juga berbeda, akan tetapi tenta menpunyai konsep yang sama. Setelah itu, subjek SKR mengumpulkan informasi dengan melihat soal yang ada dibuku paket sebagai referensi subjek dalam mengembangkan ide menjadi suatu soal.

d. Menerapkan ide

- Setelah subjek SKR memilih ide, mengumpulkan informasi, serta mengembangkan. Subjek SKR menggunakan ide-ide yang telah dipilih untuk membuat soal. Subjek SKR menggunakan ide tersebut untuk membuat soal dengan cara merangkai kata-kata terlebih dahulu kemudian disusun hingga menjadi soal. Soal pertama yang dibuat subjek yaitu soal tentang pembelian barang yang terpisah dari paket yang diberikan. Soal kedua yang dibuat subjek SKR tidak menggunakan informasi yang diberikan pada tes akan tetapi masih ada hubungan dengan informasi yang diberikan pada tes. Setelah membuat dua soal, subjek membuat penyelesaian dari soal yang telah dibuat. Setelah membuat soal dan penyelesaiannya, subjek memeriksa kembali soal dan 
penyelesaian yang dibuat untuk mengecek masih ada yang salah atau tidak. Subjek SKR yakin bahwa soal dan penyelesaiannya sudah benar dan sesuai. Subjek juga berpendapat bahwa soal yang dibuat mempunyai keterkaitan dengan informasi yang diberikan pada tes karena soal tersebut berhubungan dengan pembelian barang dalam paket sebagaimana informasi yang diberikan pada tes. Dalam hal ini, soal dan strategi penyelesaian yang dibuat subjek SKR benar meskipun waktu yang digunakan cenderung lama. Hal ini sejalan dengan pendapat Kagan (1966) yang menjelaskan bahwa siswa yang bergaya kognitif reflektif cenderung menggunakan waktu yang lama akan tetapi jawaban yang dihasilkan cenderung benar. Berdasarkan hasil dan pembahasan diatas, proses berpikir kreatif subjek SKI dan SKR dalam mengajukan masalah pada tahap mensintesis ide dimulai dengan membaca dan mencermati informasi. Subjek SKI dan SKR pada tahap ini mampu memahami informasi dengan baik walaupun subjek SKI menggunakan waktu yang lebih singkat dalam memahami informasi dari pada subjek SKR. Pada tahap membangun ide, subjek SKI hanya mampu membangun satu ide untuk dibuat soal. Sedangkan subjek SKR pada tahap membangun ide, subjek mampu membangun ide yang lebih dari satu. Pada tahap merencanakan penerapan, subjek SKI langsung menggunakan ide yang diperoleh dengan mengumpulkan informasi yang mendukung yaitu dari pengalaman mengerjakan soal. Sedangkan subjek SKR pada tahap merencanakan penerapan, subjek SKR memilih ide yang ia dapat menyelesaikan, kemudian mengumpulkan informasi yang mendukung baik dari buku paket maupun pengalaman mengerjakan soal. Padatahap menerapkan ide, subjek SKI merealisasikan ide untuk membuat soal. Soal yang dibuat subjek SKI tidak mempunyai keterkaitan dengan informasi pada tes, hal tersebut menunjukkan bahwa subjek SKI kurang cermat dalam memahami petunjuk dari informasi yang diberikan. Sedangkan subjek SKR pada tahap menerapkan ide, merealisasikan ide-ide yang dipilih untuk membuat soal. Soal yang dibuat oleh subjek SKR mempunyai keterkaitan dengan informasi yang diberikan. Hal tersebut menunjukkan bahwa terdapat perbedaan tingkat kecermatan yang dimiliki subjek SKI dan subjek SKR. Subjek SKR mempunyai tingkat kecermatan yang lebih tinggi daripada subjek SKI. Sehingga dari penelitian proses berpikir kreatif siswa bergaya kognitif impulsif dan reflektif dalam mengajukan masalah yang telah dilakukan menunjukkan bahwa siswa yang mempunyai gaya kognitif reflektif cenderung lebih kreatif dalam mengajukan masalah dari pada siswa yang mempunyai gaya kognitif impulsif.

Penelitian tentang proses berpikir kreatif dalam mengajukan masalah matematika juga dilakukan oleh Arvianto (2018). Penelitian yang membahas tentang proses berpikir kreatif mahasiswa dalam mengajukan masalah ditinjau dari perbedaan gender, hasil penelitian menunjukkan bahwa proses berpikir kreatif mahasiswa laki-laki dan perempuan tidak memiliki perbedaan yang signifikan dalam tahap persiapan, akan tetapi terdapat perbedaan pada tahap inkubasi, iluminasi, dan verifikasi. Penelitian lain tentang proses berpikir kreatif siswa dalam mengajukan masalah juga dilakukan oleh Hidayat dan Anggraini (2019). Hasil penelitian menunjukkan bahwa dalam proses berpikir kreatif dalam mengajukan masalah, masing-masing kategori, yaitu kategori 1 (IQ 110-119), kategori 2 (IQ 100-109), dan kategori 3 (90-99) hanya melewati 3 tahap proses berpikir kreatif yaitu tahap persiapan, iluminasi, dan verifikasi. Meskipun melewati 3 tahap proses berpikir yang sama akan tetapi proses berpikir kreatif ketiga kategori berbeda-beda. Kemudian Penelitian tentang gaya kognitif impulsif dan reflektif juga dilakukan oleh Kagan (1966), Rozencwajg \& Corroyer (2005), Warli (2010), dan Al-Silami (2010), Azhil dkk (2017), dan Ramadhan dkk (2019) bahwa seseorang yang bergaya kognitif impulsif cenderung menggunakan waktu yang singkat dalam menyelesaikan masalah yang diberikan, akan tetapi kurang cermat sehingga jawaban yang dihasilkan cenderung salah. Seseorang yang bergaya kognitif reflektif cenderung menggunakan waktu yang lama dalam menyelesaikan masalah yang diberikan, akan tetapi, cermat dan teliti sehingga jawaban yang dihasilkan cenderung benar.

Berdasarkan penelitian yang telah dilakukan dan penelitian-penelitian yang relevan menunjukkan bahwa setiap siswa memiliki proses berpikir keatif yang berbedabeda. Begitu pula dengan siswa yang mempunyai gaya kognitif yang berbeda maka proses berpikir kreatif yang dimiliki siswa juga berbeda-beda. Sehingga penelitian ini mendukung penelitian tentang proses berpikir kreatif siswa dalam mengajukan masalah dari Arvianto (2018) dan Hidayat dan Anggraini (2019) dan juga penelitian gaya kognitif impulsif dan reflektif dari Kagan (1966), Rozencwajg \& Corroyer (2005), Warli (2010), dan AlSilami (2010), Azhil dkk (2017), dan Ramadhan dkk (2019).

\section{PENUTUP}

\section{Simpulan}

1. Proses berpikir kreatif siswa bergaya kognitif impulsif dalam mengajukan masalah matematika.

Pada tahap mensintesis ide yang dilakukan subjek pertama kali yaitu membaca dan memahami informasi yang diberikan pada tes. Subjek tidak memerlukan waktu yang lama untuk memahami informasi yaitu sekitar 10 menit. Kemudian subjek menyimpulkan bahwa informasi yang diberikan berhubungan dengan proses pembelian barang. 
Pada tahap membangun ide, subjek mencoba untuk mengingat konsep yang relevan dengan informasi yang diberikan yaitu tentang pembelian barang. Setelah itu, konsep yang relevan tersebut akan digunakan subjek membangun ide dengan mengaitkannya dengan informasi pada tes. Sehingga subjek mampu membuat sebuah ide yaitu tentang penjualan barang akan tetapi konsepnya agak berbeda dengan informasi pada tes.

Pada tahap merencanakan penerapan, subjek mengumpulkan informasi yang berkaitan dengan ide yang dimiliki, kemudian menggembangkan ide dengan mengingat kembali pengalaman yang ia miliki untuk digunakan dalam membuat soal.

Pada tahap menerapkan ide, subjek merealisasikan ide yaitu dengan membuat soal, memeriksa kembali soal dan penyelesaian yang telah dibuat apakah sesuai dengan informasi yang diberikan dalam tes. Soal yang dibuat subjek yaitu tentang pemberian diskon untuk setiap paket yang telah ditentukan. Ia yakin bahwa soal yang telah dibuat sudah benar.

2. Proses berpikir kreatif siswa bergaya kognitif reflektif dalam mengajukan masalah matematika.

Pada tahap mensintesis ide, pertama yang dilakukan subjek yaitu membaca dan mencermati informasi yang diberikan berulang-ulang. Subjek mengingat konsep yang relevan dengan tes yaitu tentang pembelian barang. Pada tahap ini subjek membutuhkan waktu yang relatif lama yaitu sekitar 15 menit.

Pada tahap membangun ide, subjek menggabungkan konsep yang relevan yang pernah ia kerjakan yaitu tentang pembelian barang dengan informasi yang diberikan pada tes. Dalam hal ini subjek dapat membuat lebih dari satu ide yaitu tentang penjualan barang akan tetapi terpisah dari paket.

Pada tahap merencanakan penerapan, subjek memilih ide yang mempunyai keterkaitan dengan informasi yang diberikan pada tes agar soal yang dibuat sesuai dan juga memilih ide yang sekiranya ia dapat menyelesaikan. Subjek mengembangkan ide yang telah dipilih dengan melihat soal yang ada dibuku paket sebagai referensi, serta memilih ide lain untuk membuat soal yang berbeda.

Pada tahap menerapkan ide, subjek merangkai katakata dan disusun untuk dijadikan soal. Subjek membuat dua soal, kedua soal tersebut hampir sama yang berbeda hanya nama barang. Soal kedua yang dibuat subjek tidak menggunakan informasi yang diberikan pada tes. Subjek memeriksa kembali soal dan strategi penyelesaian agar tidak ada kesalahan. Subjek yakin bahwa soal dan strategi penyelesaian yang dihasilkan sudah benar.
Berdasarkan hasil penelitian, terdapat beberapa saran yang dapat diberikan kepada guru dan peneliti lain yang ingin melakukan penelitian yang relevan yaitu sebagai berikut.

1. Berdasarkan hasil penelitian menunjukkan bahwa adanya perbedaan siswa bergaya kognitif impulsif dan siswa bergaya kognitif reflektif. Siswa bergaya kognitif reflektif cenderung lebih cermat dalam memahami informasi daripada subjek bergaya kognitif impulsif. Oleh Karena itu, sebaiknya guru dapat merancang model pembelajaran dengan memerhatikan gaya kognitif yang dimiliki oleh siswa agar semua siswa dapat lebih cermat dalam memahami materi pembelajaran.

2. Kajian penelitian ini hanya terbatas pada pengajuan masalah pada materi SPLDV (Sistem Persamaan Linier Dua Variabel), maka perlu dilakukan penelitian yang sejenis menggunakan materi yang berbeda agar didapat hasil penelitian mendalam tentang proses berpikir kreatif siswa pada materi yang lain.

\section{DAFTAR PUSTAKA}

Al-Silami, T. A. 2010. A Comparison of Creative Thinking and Reflective-Impulsif Style in Grade 10 Male Student From Rural and Urban Saudia. Disertasitidakditerbitkan. Melbourne: Victoria University.

Arofah, Nur Diana dan Masriyah. 2019. Profil Pengajuan Masalah Matematika Siswa SMP Ditinjau dari Gaya Kognitif Impulsif dan Reflektif. Jurnal Ilmiah Pendidikan Matematika. Vol 8(2). Hal 209-215.

Arvianto, Ilham Rais. 2018. Proses Berpikir Kreatif Mahasiswa dalam Pengajuan Masalah Matematika Ditinjau dari Perbedaan Gender. Jurnal Ilmiah Pendidikan Matematika. Vol 6(2). Hal 99-108.

Azhil, Imam Muhtadi. dkk. 2017. Profil Pemecahan Masalah Matematika Siswa Ditinjau dari Gaya kognitif Impulsif dan Reflektif. Jurnal Review Pembelajaran Matematika. Vol 2(1). Hal 60-63.

Evans, J. R. 1991. Creative Thinking in the Decision and Management Sciences. Ohio. South-Western Publishing Co. [Online].https://books.google.co.id/books?op=lookup \&id=xAIKAQAAMAAJ\&continue. Diakses pada tanggal 02 Februari 2020.

Fitriatien, Sri Rahmawati. dkk. 2019. Optimalisasi HOTS dalam Pembelajaran Matematika Melalui Budaya Literasi pada Era Industri 4.0. Prosiding Seminar Pendidikan Matematika 2019. Surabaya, 04 Mei 2019: Adi Buana University Press.

Hidayat, Akhmad Faisal. Peni Anggreni. 2019. Proses Berpikir Kreatif Siswa dalam Pengajuan Masalah Matematika. Jurnal Ilmiah Dikdaya. Vol 9(2). 
Kagan, J. 1966. "Reflection-Impulsivity: The Generality an Dinamics Of Conceptual Tempo".Journal of Abnormal Psychology. Vol. 71(1): pp. 17-24.

Nurmasari, Nina. dkk. (2014). Analisis Berpikir Kreatif Siswa Dalam Menyelesaikan Masalah Matematika Pada Materi Peluang Ditinjau Dari Gender Siswa Kelas XI IPA SMA Negeri 1 Kota BanjarBaru. Jurnal Elektronik Pembelajaran Matematika. Vol. 2(4). Hal 351-358.

Pagiling, Sadrack Luden. 2017. Representasi Matematis Peserta didik Kelas VIII yang Bergaya Kognitif Reflektif dan Impulsif dalam Memecahkan Masalah Matematika. Tesis tidak diterbitkan. Surabaya: PPs Universitas Negeri Surabaya.

Prianggono, Agus, dkk. 2013. Analisis Proses Berpikir Kreatif Siswa Sekolah Menengah Kejuruan (SMK) dalam Pemecahan dan Pengajuan Masalah Matematika pada Materi Persamaan Kuadrat. Jurnal Pembelajaran Matematika. Vol 1(2).

Ramadhan, Fahmi. dkk. 2019. Proses Berpikir Siswa SMP dalam Pemecahan Masalah Matematika Soal Cerita Ditinjau dari Gaya Kognitif Reflektif dan Impulsif. Jurnal Peluang. Vol 7(1). Hal 151-156.

Royhan. Muhammad. 2018. Proses Berpikir Kreatif Siswa dalam Mengajukan Masalah Ditinjau dari Perbedaan Jenis Kelamin. Skripsi Tidak Diterbitkan. Surabaya: Universitas Negeri Surabaya.

Rozencwajg, P. and Corroyer, D. 2005. Cognitive Processes in the reflective-Impulsive Cognitive Style.
The Journal of Genetic Psychology. Vol 166(4), hal. 451-452.

Silver, E.A., Mamona-Downs, J., Leung, S.S., \& Kenney, P.A. (1996). Posing Mathematical Problems: An Exploratory Study. Journal for Research in Mathematics Education. Vol. 27(3): pp. 293-309.

Siswono, Tatag Y. E. 2008. Model Pembelajaran Matematika Berbasis Pengajuan dan Pemecahan Masalah untuk Meningkatkan Kemampuan Berpikir Kreatif. Surabaya: UNESA University Press.

Siswono, Tatag Yuli Eko. 2016. "Diklat Guru Matematika SMP Se-Kabupaten Jember". Makalah disajikan dalam, Jember, 25-29 Januari 2016.

Siswono. Tatag Y. E. 2007. Konstruksi Teoritik tentang Tingkat Berpikir Kreatif Siswa dalam Matematika. Jurnal Pendidikan, Forum Pendidikan \& Ilmu Pengetahuan. Vol 2(4).

Slameto. 2013. Belajar dan Faktor-Faktor yang Mempengaruhinya. Jakarta : Rineka Cipta.

Warli. 2010. Kreativitas Siswa SMP yang Bergaya Kognitif Reflektif atau Impulsif dalam Memecahkan Masalah Geometri. Disertasi tidak diterbitkan. Surabaya: Pasca Sarjana UNESA.

Yu, Kesheng. 1997. The Effect of Cognitive Tempo and Training in A Hypermedia Learning Environment on Navigation Patterns, Learning Achievement, and SelfEfficacy. Disertasi tidak diterbitkan. Texas: Texas Tech University.

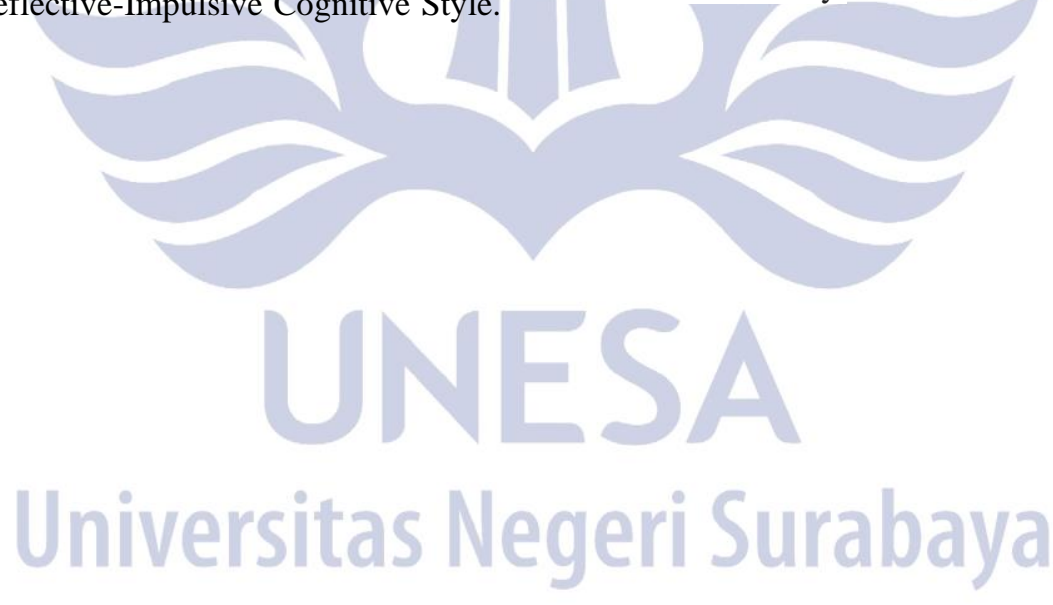

